\title{
Resenha: a pitada de pimenta de Paul McCartney em The Lives of John Lennon de Albert Goldman; bastidores do disco Sgt. Pepper's Lonely Hearts Club Band
}

\author{
Resenha de Fausto Borém (UFMG, Belo Horizonte, MG) \\ fborem@ufmg.br
}

GOLDMAN, Albert. The Lives of John Lennon. New York: William Morrow and Co., 1988. Preço não disponivel.

\begin{abstract}
Resumo: Resenha sobre o capitulo Paul grinds pepper do livro The Lives of John Lennon (1988) de Albert Goldman, que traz dados relevantes, pouco conhecidos e polêmicos sobre os bastidores do disco LP Sgt. Pepper's Lonely Hearts Club Band, lançado pelos Beatles em 1967 e o disco compacto com as faixas Penny Lane e Strawberry Fields forever, também lançado em 1967. Traz também o contexto histórico que precedeu a mudança estética mais radical da carreira dos Beatles, especialmente as gravações dos discos Rubber soul (1965) e Revolver (1966).
\end{abstract}

Palavras chave: Sgt. Pepper's Lonely Hearts Club Band; biografias de Albert Goldman; John Lennon e Paul McCartney.

Review: Paul McCartney grinds pepper in The Lives of John Lennon by Albert Goldman; behind the scenes with the Sgt. Pepper's Lonely Hearts Club Band

Abstract: Review of the chapter Paul grinds pepper from the book The Lives of John Lennon (1988) by Albert Goldman, which brings relevant, lesser known and controversial data on the LP Sgt. Pepper's Lonely Hearts Club Band released by the Beatles in 1967, and also the compact disc with the tracks Penny Lane and Strawberry Fields forever, also released in 1967. It also brings the historical context of the most radical aesthetic turn in the career of the Beatles, especially the recordings of Rubber soul (1965) and Revolver (1966).

Keywords: Sgt. Pepper's Lonely Hearts Club Band; biographies by Albert Goldman; John Lennon and Paul McCartney.

\section{1 - Introdução}

A habilidade de abordar o lado polêmico de personalidades marcou a carreira do biógrafo norte-americano Albert Goldman desde seus tempos de universidade. Para tema de sua tese de doutorado, escolheu os mecanismos de plágio nos famosos escritos jornalísticos de Thomas Penson de Quincey, tese que mais tarde foi publicada como The Mine and the mint: sources for the writings of Thomas de
Quincey (1965). Após obter seu Ph. D., manteve o hábito acadêmico de, antes de escrever, se munir de ampla revisão bibliográfica e exaustiva pesquisa de campo, especialmente por meio de entrevistas. Seu primeiro grande sucesso veio com a biografia Ladies and Gentlemen - Lenny Bruce!!!, muito elogiada por personalidades também polêmicas, como o escritor Norman Mailer (1923 - 2007) e a crítica 
de cinema Pauline Kael (1919-2001). Por outro lado, já nesse best-seller, atraiu a ira de amigos do biografado, que reclamaram da exposição de fatos da vida privada do comediante. Mas foi com Elvis (1981), biografia que foi chamada de "genocídio cultural" pelo crítico de rock Greil Marcus (GRIMES, 1994), que Goldman despertou a ira de milhões de fãs de outro biografado: o superstar do rock de Memphis. Apesar do sucesso da publicação, a revolta dos fãs foi recebida por Goldman, segundo o crítico Tom (GRAVES, 2012), como um cutucar a onça com vara curta: ". . . Goldman se sentiu tão escorraçado e agredido pela hostilidade em relação ao seu livro Elvis, o qual ele considerava uma biografia verdadeira e precisa, que sentiu que não tinha mais nada a perder se exagerasse algumas coisinhas no livro sobre Lennon. ..."

No ano em que lançou The Lives of John Lennon (1988), Goldman reafirmava, com seu estilo ácido e, muitas vezes pessimista e mórbido, que seus livros eram "uma dose fria de realidade" (LOS ANGELES TIMES, 2012). De fato, ele não poupa nenhuma das dezenas de personalidades que habitam seu enciclopédico livro de 719 páginas, cujos focos são a vida do Beatle (do nascimento ao assassinato) e de sua esposa Yoko Ono. 0 período de intensa pesquisa do livro, que durou quase seis anos, incluiu uma busca em vastos materiais da mídia publicados ao longo de quase 20 anos, pelo menos cinco biografias autorizadas (DAVIES, 1968; COLEMAN, 1984; GAINES, 1983; SHOTTON e SCHAFFER, 1983; PANG e EDWARDS, 1983), quatro livros analíticos (MARTIN e HORNSBY, 1980; MELLER, 1973; LEWISOHN, 1986; GREEN, 1983) e, especialmente, quase 1.200 entrevistas que conduziu pessoalmente ou por sua equipe. Dessas, destacam-se as entrevistas de John Lennon a Jann WENNER (1970), a Peter MCCABE e Robert D. SCHONFELD (1984), a David SHEFF (1982) e ao próprio Albert GOLDMAN (1970). Como a citação das fontes ao longo do imenso livro tornaria o fluxo da leitura inviável, Goldman optou por listar suas fontes apenas uma vez e, infelizmente, amontoadas ao final, por períodos cronológicos. Por isso, listo apenas algumas fontes principais ao final da resenha.

Em meio a um livro repleto de imprevisíveis e chocantes revelações, a maioria delas não diretamente relacionada com o legado musical dos Beatles ou o de John Lennon pós-Beatles, escolhi de trazer ao leitor, em português, o engenhoso texto de Goldman em Paul grinds pepper (gentilmente cedido pela Editora William Morrow), contido no $26^{\circ}$ dos 74 capítulos de seu livro, que ainda não tem tradução para o português e cujo original também não pode ser comprado com facilidade no Brasil, nem mesmo pela internet. Esse trecho do livro traz materiais muito relevantes e pouco conhecidos sobre a principal mudança estética dos Beatles, refletida não apenas no disco Sgt. Pepper's Lonely Hearts Club Band, mas também nos seus antecessores Rubber soul e, pincipalmente, Revolver, além do compacto lançado quatro meses antes de Sgt. Pepper e que contém as faixas Penny Lane e Strawberry Fields forever.
Sgt. Pepper foi pioneiro em vários aspectos. Segundo o artista pop britânico Peter Blake, autor da capa do disco (BEATLES, 1967/1987, p.26), Sgt. Pepper foi o primeiro disco a ter as letras das músicas impressas na capa e a incluir brindes (bigode, cartão, insígnia e button de papel) e um dos primeiros a ter capa dupla. Se a EMI de fato atendesse a todas as demandas dos Beatles, o disco não seria preto, mas em vinil colorido, e conteria também lápis e guloseimas (BRINK, 2013). Foi também o primeiro disco planejado para ser ouvido continuamente, sem separação entre as faixas. Segundo o engenheiro de som Geoff Emerick, que coordenou a parte técnica das gravações do Sgt. Pepper (BEATLES, 1967/1987, p.4),

\begin{abstract}
"os Beatles insistiram que tudo em Sgt. Pepper tinha de ser diferente. . . então tudo foi distorcido, limitado, comprimido ou tratado com equalização excessiva. Colocamos microfones diretamente nas campanas do instrumentos de metal. Usamos headfones como microfones ligados aos violinos. Aplicamos bastante eco nos vocais, passamos pelo circuito do alto-falante Leslie e, depois, jogamos dentro de um órgão Hammond. Usamos osciladores gigantes primitivos para variar a velocidade dos instrumentos e vocais; cortamos a fita gravada em pedaços $e_{\text {, }}$ depois, colamos de cabeça para baixo e de trás para frente".
\end{abstract}

Mark Lewisohn (BEATLES, 1967/1987, p.4) se lembra de uma brincadeira que foi incluída no álbum:

\begin{abstract}
"O finalzinho do álbum é um bom exemplo das maquinações avançadas de técnicas de estúdio aplicadas em Sgt. Pepper. Depois que as últimas gotas de som do acorde de piano martelado em $A$ Day in a life se evaporam, vêm alguns segundos com uma nota de 15 quilohertz, colocada ali a pedido de John - apenas para incomodar seu cachorro. Então, como um coup de grâce, sobrevêm alguns segundos de besteiras ditas pelos Beatles, gravadas, cortadas e coladas ao acaso para que, de acordo com George Martin, os compradores do vinil que não tivessem um auto return no seu tocadiscos se perguntariam 'Que diabos é isso?' e ouviriam aquele ruido curioso se repetindo ad infinitum no sulco concêntrico".
\end{abstract}

0 marco referencial estabelecido por Sgt. Pepper repercutiu posteriormente não apenas na sonoridade das bandas de rock, mas também nas suas concepções gráficas. Lauren BRINK (2013) menciona algumas capas pós-Sgt. Pepper. Em Satanic Majesties Request dos Rolling Stones, também se vê uniformes coloridos, objetos e um cenário psicodélico. 0 capa e o próprio título do disco We're only in it for the money [Só estamos nessa por dinheiro] de Frank Zappa e sua banda The Mothers of Invention brincam como fato de que na capa dos Beatles só estavam pessoas que não cobraram cachê. No disco de paródias ao Sgt. Pepper da banda The Rutles, cujo título é Sgt. Rutter's Only Darts Club Band, a capa é a mesma, exceto pela troca dos nomes do disco no bumbo e da banda no canteiro de flores. Já na versão jazz fusion do Sgt. Pepper do japonês Jun Fukamachi, lançada pelo selo EMI Toshiba (LF-95014) em 1977, os personagens e objetos da capa estão todos de costas.

Esta resenha também visa dar suporte para o artigo de Sarah Etlinger, publicado às p. 43-52 neste volume de Per Musi, no qual ela discute o disco Sgt. Pepper sob a perspectiva da arte pop, da fotomontagem e da história do design das capas de discos. 
0 texto, aqui traduzido e dividido nas nove seções abaixo, apresenta a crescente tensão na relação entre John Lennon e Paul McCartney, com foco (1) no abuso de drogas do primeiro e na tomada da liderança da banda pelo segundo; (2) nos antecedentes já revelados nos álbuns Revolver e Rubber soul (3) nos desafios das limitações técnicas de gravação que não impediram as inovações estéticas da banda; (4) no processo composicional aleatório dos Beatles na música pop e no papel do "quinto e erudito Beatle" George Martin; (5) na estética musical do "novo" e do "velho" em Sgt. Peppere (6) nos bastidores no processo de criação da revolucionária capa do disco.

\section{2 - Paul ganha terreno; John perde...}

"As fotos de John Lennon tiradas durante as sessões de gravação do disco Sgt. Pepper's Lonely Hearts Club Band [A Banda dos corações solitários do Sargento Pimenta] são inquietantes. Ao invés da típica foto de Lennon em um pub com a boca aberta, olhos arregalados, a face inteira como uma máscara de palhaço, temos aqui um rapaz que subitamente envelheceu cerca de 40 anos. Os olhos atrás de seus óculos de vovó parecem olhos de peixe morto. Seu bigode caído e ressecado parece pertencer à face de um velhote. Sua postura encurvada é a de um porteiro decaído da porta dos fundos de um teatro. Barry Miles [GOLDMAN, 1988, p.190], um dos melhores amigos de juventude de Paul McCartney e frequentador assíduo das sessões de gravação, diz que: 'John planejou a destruição de seu ego. Conseguiu'.

A morte de seu ego, resultado de doses pesadas de LSD e do Tibetan book of the dead, ${ }_{1}^{1}$ poderia ser a razão da repentina metamorfose de John Lennon no típico aposentado do seguro social. Mudanças drásticas como essa se tornaram lugar comum nos anos de 1960, à medida que a cena do rock se transformou na cena das drogas. Mas dois fatos tornam esta interpretação intangível. Primeiro, John nunca parava de usar ácido enquanto gravava. Segundo, seu temperamento irascivel despareceria assim que as sessões terminavam. Pode-se especular outras razões, como provavelmente uma droga mais forte do que ácido ou alguma perturbação emocional intensa. $\mathrm{Na}$ verdade, ambos os fatores estavam acontecendo.

John estava sufocado de ressentimento, porque sentia que Paul estava tentando ter nas mãos o controle dos Beatles. Esta ameaça já estava na mente de John há alguns anos, talvez desde o momento em que conheceu Paul, que se mostrou de cara ser um 'sabichão' e um grande talento musical. Esse embate entre suas personalidades naturalmente conflitantes não havia se deflagrado antes porque Paul era mais jovem e menos experiente do que John. A relação entre eles ficou, de certa maneira, em stand by porque separavam claramente as esferas de suas autoridades. Paul, um despachado do show biz, desempenhava o papel de homem de frente da banda nos palcos e, fora dos palcos, era o gerente funcional da banda. John, que se posicionou orgulhosamente como 'o artista' desligado, há muito estava satisfeito de ser a estrela dos discos dos Beatles. Durante anos, ele ficou com todos os lados A dos compactos que gravavam e 0 filé das faixas dos discos completos. Ser o leading vocal do grupo se tornou seu símbolo de liderança.

Embora o público tenha convictamente criado a imagem de que os dois líderes da banda curtiam uma relação pessoal e próxima entre si, isso nunca ocorreu. John os descrevia como dois soldados na mesma trincheira: cada um tinha a vida do outro nas mãos, mas quando o tiroteio dava uma trégua, não tinham o desejo de permanecer juntos. Nas viagens, John se alojava no mesmo quatro de George, enquanto Paul ficava com Ringo. 0 compartilhamento de confidências não ultrapassava esses momentos 'de caserna'. Quando the perguntavam sobre a relação de Paul com Linda Eastman, John respondia que ele e Paul há muito tempo deixaram de conversar assuntos pessoais. Não mais socializavam juntos ou transitavam nos mesmos círculos. Houve apenas um momento na farta literatura sobre os Beatles no qual podemos perceber de relance como John Lennon de fato se sentia em relação a Paul McCartney antes da dissolução da banda.

Eles estavam filmando Help! na Suiça. De volta ao estúdio, enquanto retiravam as pesadas roupas de neve, escutavam as fitas com as gravações de suas últimas canções. Depois de ouvir três faixas de Paul, John resmungou: 'Acho que gosto mais de suas canções do que das minhas'. Dúvida, inveja e medo sobre quem seria o melhor compositor: esses eram os verdadeiros sentimentos de John em relação a Paul.

Quando Lennon ficava prostrado devido a um 'Budha lisérgico', destruía o equilibrio que cuidadosamente construía com seus parceiros. Quanto mais passivo e retraído ele ficava, mais ativo e engajado seu rival, Paul, se tornava: então passava a bombardear os outros Beatles com suas descobertas e inspirações, de Vivaldi a Stockhausen, de avançadas técnicas de edição de tapes até aos sons excêntricos do protosintetizador em voga, o Mellotron. ${ }^{2}$ Inevitavelmente, Paul se tornou a força motriz do Beatles."

\section{3 - Antecedentes: o álbum Revolver, depois de Rubber soul}

"Os primeiros sinais da ascendência de Paul sobre os colegas aconteceram em Revolver, o mais importante dos álbuns de canções ajuntadas dos Beatles. Este disco histórico completa uma transição que já havia se iniciado com o disco Rubber soul e que marca a passagem do rock ' $n$ ' roll ao 'rock', termo deliberadamente adotado pelos experts da música para distinguir os estilos da década de 1960 do estilo da década de 1950. Rock passou a significar letras sofisticadas e espirituosas falando de temas sérios. Rock passou a significar uma enxurrada de novas sonoridades e idiomas musicais de diversas eras e regiões. Acima de tudo, rock passou a significar a nova consciência psicodélica e uma sensibilidade que entrou em cena por meio da ampla utilização do LSD. 
0 primeiro sinal que o disco Revolver nos dá de que estamos entrando em uma nova era vem dos seus sulcos mais externos. Quando a agulha começa a percorrer o disco, ao invés de ouvirmos uma explosão de música, nos deparamos com os sons do microfone aberto no estúdio, com os Beatles se preparando para gravar, à medida que uma voz com sotaque de Liverpool conta (depois de tossir): 'Um, dois. . . Essa abertura do tipo cinema varieté - que ressalta que Revolver não é um produto manufaturado impessoal, mas o trabalho de homens de carne e osso, reais em estúdio iniciou um novo jogo no qual bandas de rock começaram a brincar com realidade e ilusão da mesma forma que dramaturgos e cineastas já faziam há bastante tempo.

0 próximo e drástico sinal de mudança estilistica em Revolver foi o tema da primeira canção - impostos. Para o adulto comum, falar sobre o pagamento de impostos sempre foi um tema preferido. Por isso, ao apontar seu revólver para o cobrador de impostos e dar o primeiro tiro do disco, os Beatles mataram sua longa identificação com os adolescentes, se alinhando com o público mais maduro e preocupado que poderia apreciar suas reclamações amargas e sua audácia de vociferar suas queixas em um meio consagrado aos suspiros de amor.

À medida que avançamos nos sulcos de Revolver, cada faixa oferece não apenas uma sonoridade nova, mas também uma perspectiva totalmente diferente. 0 ecletismo, que sempre foi uma das características mais marcantes dos Beatles, agora explode em uma grande mostra de diversidade artística. Eleanor Rigby aponta para o passado da época dos lampiões de gás, com seu pulsante quarteto de cordas e elenco de personagens dickensonianos, enquanto que Tomorrow never knows, com a voz de robô cantando sobre um mar de sons da selva, rabecas de rodeio e riffs raivosos de guitarra, gesticula animadamente para o futuro fármaco-psicodélico que se aproxima. Entre estes dois extremos estão outras joias: uma cômica cantoria de rua - Yellow submarine [considerado por muitos como uma canção sobre o barbitúrico Nebumtal], (que são comprimidos amarelos na forma de submarino); For no one, que soa como um musical de salão edwardiano; Good bye Sunshine, como sua atmosfera espevitada dos volteios com chapéu de palha das quadrilhas; e assim por diante formando a maior diversidade musical que jamais apareceu no cardápio da música pop.

Embora os Beatles planejassem cuidadosamente a ordem das músicas nos discos, o efeito de se ouvir Revolver sem interromper o disco é com se sentar em um daqueles carrinhos bate-bate, nos quais subitamente você bate no para-choque de alguém, sai pela tangente e bate novamente em outro carro. Obviamente, você precisa de um amortecimento para sua cabeça e algo que deixe seu corpo relaxado como se fosse embarcar em uma viagem irresponsavelmente. Mas essa soltura já era esperada por parte do ouvinte, uma vez que a ligação entre música popular e drogas se forjou secretamente nos bastidores do jazz e se tornou, na década de 1960, a precondição universalmente reconhecida e aceita para fazer os discos.

Quem foi o principal responsável por este álbum alucinógeno, tão cheio de ilusões como Tunnel of love? Até agora a resposta seria 'John Lennon', porque em todos os momentos da história pregressa dos Beatles tinha sido John, com seu notável sentido de saber onde música e público se encontravam, ele que catapultou a banda para um estágio mais alto de realização. Mas agora tudo tinha mudado. Paul conseguiu se emparelhar com John enquanto compositor ao escrever Eleanor Rigby que, apesar de seu clima sentimental, é tão marcante quanto Tomorrow never knows, o melhor esforço composicional no disco. Mais do que isso, se essas canções funcionam como testemunhas, John e Paul não eram seres semelhantes, mas opostos, tão diferentes em arte quanto sempre foram na vida.

Mas não era o caso dos Beatles serem bifocais. Paul se ocupou da tarefa de utilização altamente inovadora da música e suas sonoridades, da linguagem e dos versos, dos valores de produção e das técnicas de gravação em todo o álbum. Revolver, como uma viagem de Colombo em busca de um admirável mundo novo, é inspirado, sustentado e impregnado com a descoberta do olhar agudo de Paul sobre todas as maravilhas da cena cultural de Londres, aquele vasto mundo novo que se abriu à sua frente na sua estadia com a família Asher. 0 fechado e altamente defensivo Lennon nunca teria se abrido para todas essas influências e experiências se Paul não o tivesse ora seduzido ora desafiado neste esforço. Ironicamente, foi Lennon que, uma vez convertido, puxou o carro dos Beatles na viagem de descoberta dos confins mais longínquos. Mas o mundo inteiro já estava caindo na mesma direção."

\section{4 - Paul assume Sgt. Pepper}

"Em novembro de 1966, quando os Beatles começaram a gravar as faixas para o álbum que se tornaria o Sgt. Pepper's Lonely Hearts Club Band, Paul se tornou, por assim dizer, o diretor artístico da banda. Sgt. Pepper's foi, desde o início, um álbum de Paul. Foi ele quem concebeu a ideia, escreveu pelo menos metade das canções, dirigiu as sessões de gravação, supervisou a mixagem e tomou frente na capa sem precedentes do disco. John Lennon estava tão incomodado por este tour de force que reclamou rancorosamente que Paul dando uma de patrão, empregando a tática do fato consumado. Podemos imaginá-lo dizendo: 'Quando Paul queria, ele aparecia com umas 20 canções boas e dizia 'vamos gravar'. E aí eu ficava p... da vida por ter de escrever uma pilha de canções. Pepper foi assim.' Mesmo que fosse verdadeira, essa fala de John não teria o impacto de uma acusação sobre Paul. Simplesmente confirma a suspeita de que o poder de Paul estava basicamente fundado na crescente apatia de John, que resultava em uma aversão ao trabalho e responsabilidade. E se Paul não viesse de vez em quando com suas '20 canções boas'? 0 que haveria acontecido com os Beatles? A resposta é que não teriam produzido o álbum que lhe trouxe 
a maior aclamação. Nem o letárgico Lennon poderia ter tido motivação para escrever alguns de suas mais memoráveis canções. Claramente, Paul estava dando um passo no vácuo criado pela delinquência de John, a fim de ter o controle da banda nas mãos e mantê-la ativa.

Para avaliar o quão benigna foi essa tomada de posição de Paul, e julgando por um padrão comum no mundo do rock, podemos compará-la com a atitude de Mick Jagger, que se livrou de Brian Jones, o fundador e líder dos Rolling Stones. Em ambos os casos, o gênio da banda se auto nocauteou por meio das drogas, se tornando uma presa fácil. Nesse ponto, o tenente ambicioso dá um golpe militar, toma o controle da organização e a leva na direção que o fundador e ex-líder reprovava totalmente. As semelhanças param por aqui, pois Paul nunca fez o menor esforço para se livrar de Lennon. Na verdade, continuou a tentar retomar a velha parceria com John até a sua morte.

Embora John tenha se ressentido do fato de Paul tomar frente, ele nunca quis encarar de fato esta questão. Ao invés de discutir o problema como um velho parceiro deveria fazer, John se recolheu e enfiou a cabeça na terra como um avestruz, fingindo de morto: não mais liderava, mas também não obedecia. Assim, não teve escolha a não ser aceitar o jogo. 0 que foi fatídico. Isso não apenas iniciou o processo de dissolução dos Beatles, mas marcou também o início de um declínio longo e mortal que, eventualmente, destruiria John Lennon."

\section{5 - Abbey Road e o velho Estúdio 2}

"John não foi o único dos Beatles a se sentir deprimido durante as gravações de Sgt. Pepper's. Todos os garotos, exceto Paul, estavam meio obnubilados pela natureza sem precedentes do evento. Foram 700 horas de estúdio, de novembro de 1966 a março de 1967, em que cada minuto foi dedicado ao próximo LP anual dos Beatles, a ser lançado na primavera. ${ }^{3} 0$ problema maior não era 0 fato de Paul tomar a liderança da banda, mas o simples fato de que os Beatles se propuseram a criar um disco que expandiria as fronteiras da gravação de música pop sem ter acesso a um estúdio que representasse o estado da arte em termos de gravação.

0 Studio 2 da Abbey Road nem de longe parecia com um estúdio de gravação de ponta da época. Construído em 1931 para a realização de discos de música erudita para a $\mathrm{HMV}^{4}$, se parecia com um austero cinema de arte branco cujos assentos foram removidos e cuja cabine de projeção foi empurrada para um canto, com acesso por meio de dois longos vãos de escada. Inconveniente e incompatível, o estúdio era também completamente desatualizado do ponto de vista técnico. A mesa de som era tão rudimentar que para se realizar um playback, os engenheiros de som tinham de refazer as conexões, um processo que podia demorar até meia hora. Os gravadores eram obsoletos, de quatro canais apenas. ${ }^{5}$ Não havia nenhum refinamento eletrônico: por exemplo, quando os Beatles precisaram daquele efeito engraçado como se estivesse falando através de um tubo na faixa Yellow submarine, ao invés do técnico simplesmente ativar um filtro, ele deu a John Lennon um tubo de papelão para falar através dele. Nesses momentos, os Beatles eram como os radialistas nos estúdios da década de 1930, como de fato, era o tipo de estúdio que tinham nas mãos!

A solução para todos esses problemas foi simples. De fato, já havia sido adotada pelos Rolling Stones há muito tempo. Os Beatles poderiam ter pegado um avião para Nova lorque, ou melhor, para Los Angeles e se beneficiar do melhor equipamento de gravação do mundo. Mas era tão típico deles não fazer isto! Sua submissão à política parcimoniosa de gravação da EMI em um estúdio obsoleto equivale à sua submissão à United Artists quando foram apresentados aos roteiros de filme que não gostaram ou, ainda, sua rendição aos fãs norte-americanos, que os tiraram dos palcos no pico de sua carreira. Os Beatles eram ambiciosos, trabalhavam duro e eram jovens muito criativos, mas também deficientes do ponto de vista mercadológico, tanto em relação às questões práticas quanto à autoconfiança que os permitiria demandar e insistir nos seus desejos. Pioneiros, mas nunca rebeldes, os Good Boys of Rock faziam o melhor com o que lhes era dado, mesmo quando se sentiam miseráveis.

Para imaginar os Beatles durante a criação do que é universalmente considerado a maior obra-prima da era do rock, devemos imaginá-los sentados nos cantos mais estranhos de uma região vasta e desolada, como figurantes em uma performance da ópera 0 Crepúsculo dos deuses. $\mathrm{Na}$ maior parte do tempo ficavam ociosos, gastando o tempo em passatempos como xadrez ou jogo de cartas, tomando chá ou comendo torradas com feijão, batendo papo com seus amigos de infância e colegas de Liverpool. Paul, nesse meio tempo, se mostrava muito atarefado, subindo as longas escadas da cabine de controle para falar rapidamente com George Martin. Então descia as escadas novamente para experimentar alguma coisa no microfone. Depois ajuntava os outros Beatles para gravar suas partes e, então, ouvir o que foi gravado, o que significava mais uma longa interrupção. Não é de se estranhar que em algumas noites, quando a espera se tornava insuportável, John Lennon subia subitamente à cabine de controle: 'Que merda vocês estão fazendo aí? Não é hora de intervalo pra café, não! Vocês têm de trabalhar sem parar porque somos os Beatles, que merda!'

Para enfrentar as noites intermináveis, os Beatles tinham de encher a cabeça com alguma coisa. É irônico que o mais celebrado disco de acid rock tenha sido criado sob a influência de um coquetel químico que remonta ao período quando Abbey Road foi construída. Uma noite, Barry Miles descobriu o segredo da paciência dos Beatles quando notou que todos quatro tinham tubos de ensaio arrolhados contendo um pó branco. Quando lhe ofereceram, perguntou precavidamente: '0 que é isso?' E ficou surpreso coma resposta: 'speedball' - ou seja, a clássica mistura de cocaína com heroína." 


\section{6 - Canções ao acaso e o quinto Beatle George Martin}

"Quando os Beatles embarcaram na longa viagem que finalmente os levaria à Pepperland, não tinham ideia onde iriam parar. Ao invés de trazer para o estúdio uma seleção de canções amadurecidas de tanto tocar, começaram o trabalho como os músicos de jazz, apenas com o embrião de uma ideia - um título da canção, um gancho, uns poucos versos rascunhados em um pedaço de papel. Por meio de improvisação coletiva, criaram suas canções na frente dos microfones, auxiliados pela cada vez mais presente ajuda de George Martin, que estava na função não apenas de produtor, mas também de compositor, arranjador, técnico de efeitos especiais, engenheiro de som e instrumentista. Esse processo colaborativo teve o lado bom e o lado ruim. A grande vantagem foi que compondo diretamente na fita de gravação, eliminaram 0 processo intermediário entre 0 conceito e 0 produto final. A desvantagem, além da grande perda de tempo, foi que os cinco colaboradores tinham mentes diferentes. George Martin frequentemente tinha dificuldades em entender o que os Beatles estavam procurando porque descreviam suas ideias de uma maneira muito vaga, em uma linguagem leiga, pouco técnica. Os quatro Beatles, ao mesmo tempo, eram indivíduos distintos e com talentos individuais muito variáveis. Assim, cada um tentava dar uma direção diferente no tratamento de uma canção.

A solução para esse problema seria uma intercomunicação, mas os Beatles, tão desenvoltos nas coletivas de imprensa e tão falantes entre os amigos, não eram bons na comunicação de suas ideias e ideais mais profundos. Paul foi quem se aproximou mais do que queria, porque fazia a banda gravar tantos takes de suas canções quanto fossem necessários para se chegar à perfeição. E então se posicionava atrás dos engenheiros de som [Geoff Emerick, como chefe, e Phil McDonald; mas também trabalharam esporadicamente sete outros: no processo Richard Lush, Adrian Ibbetson, Malcolm Addey, Ken Townsend, Peter Vince, Graham Kirkby, Keith Slaughter (BEATLES, 1967/1987, p.5-6)], monitorando cada momento do processo crucial de mixagem. John, por sua vez, não tolerava muitas repetições e o tédio. Gostava de gravar com o famoso 'Um, dois, três'. Se não dava certo nos primeiros takes, seu impulso era dizer 'Que se dane!' Por isso foi punido pela sua falta de persistência, vendo algumas de suas melhores canções mutiladas. E jogava a culpa em Paul, assegurando que 'Paul subconscientemente destruiria uma grande canção'. A canção de John que mais bravamente resistiu à 'destruição' de Paul foi Strawberry Fields forever.

Lennon compôs Strawberry Fields forever durante as seis semanas entediantes que ele esteve na Espanha para as locações de How I won the war (embora John valorizasse o processo composicional espontâneo, adorando canções como Across the universe, que simplesmente 'baixaram' na sua cabeça, suas melhores obras geralmente foram fruto de gestações lentas e gradativas). Quando voltou a Londres, mostrou a nova canção para George Martin, que achou Strawberry Fields forever 'gentil' e 'adorável'. Mas no ensaio, os Beatles começaram a moldá-la como um hard rock. Pode-se perceber este processo na introdução da música. Primeiro, Paul tateia acordes místicos no Mellotron, enquanto George Harrison percorre uma escala de sonoridade mágica e brilhante em uma harpa indiana [swarmandal] - ambos sinais de que a canção é 'de outro mundo.' Então Ringo marreta com suas mãos de pedreiro - e o encanto se desfaz. Na verdade, não se pode culpar os Beatles de não entenderem a canção, quando o próprio Lennon não tinha ideia do que queria."

\section{7 - Strawberry Fields forever fica de fora}

"Invariavelmente definida como uma canção que fala de drogas e/ou infância, Strawberry Fields forever é, na verdade, sobre o senso peculiar de John da realidade, ou melhor dizendo, irrealidade, porque ele insiste que não pode dizer o que é real e que seria melhor nem tentar. Essa atitude não era simplesmente resultado do LSD; tem raizes na infância assombrada de Lennon, quando as coisas mais familiares, como a aparência de seu rosto no espelho misteriosamente mudava. Para quem foi adepto da auto hipnose a vida inteira, realidade não era algo que podia se definido em termos de clareza e fixidez; era mais um fluxo visionário.

$\mathrm{Na}$ representação desse estado de consciência cambiante e ilusório, o primeiro desafio seria encontrar uma linguagem com textura apropriada. A solução de Lennon foi simples. Ele imitou o dialeto tropeçante dos hippies e das pessoas que entram em transe, fazendo um repetido passo-prá-frente, passo-prá-trás verbal. A próxima questão era como traduzir a ambiguidade de sua mente vagante. Por isso usou como instrumento seus trocadilhos. Uma das razões pelas quais Strawberry Fields foi tão importante para Lennon é que nessa canção ele de fato deu vazão ao seu jogo de palavras. Assim no famoso trechinho sobre sua árvore, ele inventa coisas ('up a tree', 'out of his tree') para levantar as questões básicas de suas visões: elas o tornam mais alto ou mais baixo, mais inteligente ou mais louco do que o homem comum? De toda maneira, ele conclui, o tornam singular.

0 símbolo central, o orfanato da Salvation Army [Exército da Salvação] é, de fato, uma marca, carimbo ou griffe de Lennon. Para compositores comuns de música pop, mesmo geniais como Paul McCartney, a memória de Strawberry Fields forever teria inspirado uma canção que refletisse mais as alegrias da infância, como Penny Lane, uma vez que o ambiente do orfanato [vizinho da casa de Lennon] era como um playground o ano inteiro e, mesmo nas férias, continuava como um de seus locais favoritos. 'Havia algo naquele lugar que sempre fascinou John', lembra sua Tia Mimi. 'Ele podia ver tudo pela janela e adorava ir para a festa anual no jardim. Costumava ouvir a banda da Salvation Army e me puxava dizendo 'Corre, Mimi! A gente vai chegar atrasado.' E que se transformou em uma vinheta charmosa e interessante, devido à sua referência à banda 
de metais, com se fosse a banda do próprio Sgt. Peppers, álbum para o qual Strawberry Fields estava originalmente destinada e em cuja capa os Beatles planejaram posar com uniformes com os sóbrios uniformes da Salvation Army. 0 prazer de John nas memórias de sua infância pode estar nas entrelinhas da escorregadela ortográfica que converteu Strawberry Field no plural Strawberry Fields, com sua forte sugestão dos Elysian Fields [Campos Elísios].

Mas é muito característico de John Lennon que suas lembranças nostálgicas de infância se transformassem mais em um símbolo de dor do que de prazer. Ele sabia muito bem que as garotinhas de vestidos azul e branco, com seus chapéus de palha amarrados com fitas vermelhas no queixo eram órfãs como ele mesmo. Strawberry Field não era apenas o playground de Lennon: era sua casa espiritual. 0 temperamento titubeante, errático e depressivo que marcou a maior parte de sua vida tem origem no sentimento de, precocemente, sentir como estivesse em um orfanato, que o separava da vida normal e o deixava à deriva, em um limbo existencial, elemento no qual se tornou um nativo. 0 estranho mundo que a gravação evoca tem, de fato, associações com os estados alterados pelas drogas, mas as drogas apenas exageravam o estado natural do ser que se tornou John Lennon.

Strawberry Fields forever era tão importante para John Lennon que certa vez se rebelou contra a maneira como os Beatles distorceram sua inspiração. Ele disse a George Martin que a gravação não estava correta: não houve a construção do clímax e sua resolução, como toda boa gravação deveria ser. Muito menos refletia a visão alucinatória do verso. Quando Martin concordou, John pediu ao produtor para fazer algo parecido com o que havia sido feito na gravação de Eleanor Rigby de Paul McCartney, uma das primeiras gravações dos Beatles a utilizar texturas de música erudita. Martin preparou uma partitura com beeps de trompetes e gargalhadas de violoncelos que se tornaram o primeiro e mais exemplo de um gênero que poderia ser chamado de 'barock ' $n$ ' roll'. Mas Lennon ainda não ficou satisfeito.

Ligou para Martin e disse que gostou do início da versão original e da maneira como a segunda versão continuava e finalizava a canção: 'Será que dava para cortar e colar os dois pedaços?' 0 produtor, que nunca ficou livre da falta de conhecimento musical dos Beatles, replicou secamente: 'As duas versões estão em tonalidades e andamentos diferentes.' Qualquer uma dessas razões teria sossegado um músico experiente. Mas para John Lennon, as objeções de Martin eram apenas baboseiras: 'Você pode consertar isso, George', disparou John. E desligou o telefone antes que Martin pudesse dizer não.

De fato, Martin pôde consertar. Ele descobriu que acelerando em 5\% a segunda versão, que era mais lenta, poderia equiparar as alturas e andamento das duas versões. 0 corte é claramente audivel logo antes da entrada dos violoncelos, mas em uma faixa com uma mistura sonora tão carregada, quem notaria?
A gravação que surgiu após todas essas visões e revisões está a quilômetros de distância da intenção inicial de John Lennon e a razão pela qual continuou reclamando até o final de sua vida, prometendo que gravaria Strawberry Fields forever novamente, correta. Ao invés de se tornar uma canção 'gentil' e 'adorável' sobre o retorno à infância em meio a visões ondulantes, a canção que tocou em milhões de alto-falantes em todo o mundo se transformou em uma confusão fantasmagórica de imagens incompreensiveis e sons bizarros. Como Heartbreak Hotel [de Tommy Durden e Mae Boren Axton] no seu tempo, Strawberry Fields forever representou mais um símbolo acústico do que o queria dizer, mas o que de fato comunicou foi um mergulho alucinógeno no redemoinho do inconsciente mental.

No final das contas, Lennon teve de reconhecer que, ao procurar resgatar sua canção das mãos distorcidas dos Beatles, conseguiu apenas ofuscá-la inda mais na mesa de som e cabos de George Martin, que foi o autor real de todas as sonoridades relevantes daquela gravação. Por isso, o comportamento frio e de desdém de Lennon em relação a Martin anos mais tarde se deve muito à maneira com que o produtor fez e deixou de fazer por suas canções. $\mathrm{Na}$ verdade, a maioria dos Beatles ficava incomodada quando os jornalistas começaram a chamar Martin de 'o quinto Beatle'.6 Dar crédito a outrem não era algo fácil para os Garotos de Liverpool, especialmente quando sentiam a tensão na corda de outra mente os guiando por águas ainda não navegadas."

\section{8 - 0 velho e o novo no álbum Sgt. Pepper}

"As faixas Strawberry Fields forever e Penny Lane foram lançadas como disco compacto em fevereiro de 1967, com Paul ficando com o lado A porque Brian [Brian Epstein, empresário dos Beatles; GOLDMAN, p.112116] concordou que Penny Lane era mais comercial. Mas os Beatles tiveram que repensar todo o projeto do Sgt. Pepper's Lonely Hearts Club, encontrar mais duas canções, porque na Inglaterra daquela época, orientada financeiramente, não era apropriado incluir em LPs canções lançadas anteriormente em compactos. Depois de tentar várias faixas, incluindo a que se tornaria a última faixa do disco, Paul McCartney teve uma ideia fulminante. Propôs que organizariam as faixas do disco com se fossem um concerto de uma banda de coreto, com seus metais iniciando com uma abertura que seria reprisada ao s final. E cada um teria nomes típicos, como Billy Shears, e se apresentariam como personagens de uma peça de teatro, se divertindo com o estilo brega daquele tipo de entretenimento amadorístico. Paul havia acabado de chegar de San Francisco, onde as bandas começavam a usar nomes estranhos, como Big Brother and the Holding Company ou Country Joe and the Fish. Com esse mesmo espírito, ele aparece com um espetacular nome campal: Sgt. Pepper's and His Lonely Hearts Club Band.

Nada poderia ser mais característico de Paul McCartney do que a ideia do Sgt. Pepper. Embora fosse o vanguardista 
dos Beatles, no fundo era um nostálgico que adorava reviver o mundo de sua infância. Não é à toa que sua visão brilhante da Rua Penny Lane se transformou em uma de suas mais perfeitas e profundas canções - e dava o melhor de si como compositor ao 'pintar' cenas musicais que capturavam características afetivas da vida cotidiana da Inglaterra. Em particular, gostava do astral dos show biz antigos, como os alegres shows matinais do rádio, os filmes românticos e engraçados, os astros das canções com cara de irresponsáveis, os tipos de Paul Ramones [nome de Paul na época dos Silver Beatles], cantando em devaneio para filas de garotas com rabos-de-cavalo. Embora conhecesse a fama como um dos líderes da banda que antecipava o futuro, Paul McCartney era, como [o cantor, ator e comediante e norte-americano] Al Jolson ou [o cantor, ator e comediante e francês] Maurice Chevalier, um cantor de canções luminosas.

Daí o paradoxo de Sgt. Pepper, que surgiu e foi recebido como prenúncio do novo mundo da década de 1960, mas que depois de 20 anos se assenta perfeitamente no mainstream da música popular, apontando para trás tão remotamente quanto para Gilbert e Sullivan. A temática do álbum é totalmente pop: a celebração da vida ordinária das pessoas ordinárias, simbolizada por Ringo, o moderno homem comum, cantando [como seu personagem Billy Shears] With a little help from my friends. Essa canção de Paul (com uma pequena ajuda de John) foi sua última contribuição para o disco, mas sua maior importante afirmação. Ela representa perfeitamente aquela atitude que tem sido a retórica do homem comum inglês e que epitomiza a pessoa pública de Paul 'Eu, o pequeno multimilionário.' Da mesma forma, quando se despe Sgt. Pepper's de sua 'embalagem' de papel celofane (seus repiques metálicos e brilhantes, seu palimpsesto de texturas musicais e suas transições suaves) o que você descobre por debaixo é um estilo e uma atitude que está mais para old-fashioned do que para ultramoderno. $\mathrm{Na}$ canção She's leaving home o clima é positivamente vitoriano, como um episódio de um velho melodrama que se desenrola à luz de um lampião de gás, com a garota fugindo da casa paterna com um vagabundo no carro da firma, enquanto seus pobres pais lamentam em falsetes agudos e nauseantes. Para sermos mais honestos, há algumas digressões exóticas quando John olha através do espelho de Lucy [na canção Lucy in the sky with diamonds] e George desenrola seu tapete de orações indiano, mas estes são apenas uns poucos temperos estranhos misturados no vidro de pimenta caseira. 0 álbum todo é a cara de Paul - do começo ao fim.

Então, do nada, navegando como um navio fantasma congelado, com a voz desolada, em desespero, mas resignada, John Lennon [na canção $A$ Day in the life] faz soar uma eterna e triste nota enquanto apresenta uma visão da vida comum, tirada das manchetes do Morning Mail que aniquila a visão alegre de toby mug $^{7}$ de Paul McCartney. À medida que Lennon desenrola o caos surrealista da página deste jornal imaginário, de uma coluna a morte nos encara e de outra coluna salta a estranha imagem de 4.000 buracos em Blackburn [cidade próxima a Manchester]. A morte é descrita como as drogas que alienam; a exaustão do mundo faz a morte parecer um desfecho reconfortante. Os buracos inspiram um trocadilho maldoso ['Now they know how many holes it takes to fill the Albert Hall', ou seja, 'quantos buracos são necessários para se encher o Teatro Albert Hall']. A ponte da canção, um fragmento pinçado na sacola de canções de Paul, nos dá um vislumbre rápido de mais um cidadão comum de Pepperland, correndo para pegar o ônibus para o trabalho ['Woke up, fell out of bed, dragged a comb across my head']. Essa pequena tomada cinematográfica sem descanso, parecendo um comercial de TV, atravessa a tensão criada por John com tão pouca lógica quanto a sucessão de itens na página do jornal. Na próxima vez que o tema de Lennon retorna, conduz à [inesperada e] insinuante frase que propõe uma 'excitação sexual', que passa a girar como uma roda saindo de seu eixo. Transformado no som sinistro e contínuo de um dínamo se acelerando, a máquina infernal atinge, por meio de vertiginosa rotação, um clímax aterrorizante quando, finalmente, explode [no arranjo, a orquestra sinfônica tem uma improvisação coletiva que, com um tutti de glissando e crescendo, chega ao clímax em um Mi no registro agudo]. 0 último acorde, tocado no piano por muitas mãos, pode então ressoar, diminuir e desparecer como fumaça. Tudo se resolve em um acorde de Mi Maior, empregado tradicionalmente na música ocidental para simbolizar o paraíso."

\section{9 - A capa revolucionária do álbum Sgt. Pepper}

"Sgt. Pepper foi lançado em um clima cultural caloroso e fecundo, em meio a ideais e crenças fantásticas. Os hippies, inspirados pelo desejo de recuperar o núcleo criativo da vida, se sentavam ponderando sobre a capa mística do álbum em meio à fumaça de incensos chineses e tailandeses, como monges debruçados sobre iluminuras alegóricas. 0 que liam na ilustração era precisamente 0 que repousava no alto de suas mentes: a doutrina corrente de morte e renascimento. Ao interpretar os dois conjuntos [de figuras] dos Beatles ali representados, cada análise publicada nos jornais de rock ou na imprensa alternativa punha grande ênfase no contraste entre a foto monótona em preto-e-branco das figuras de cera dos Beatles, em pé ao lado do que parecia ser um túmulo; e os gloriosos Beatles nos seus uniformes de cetim resplandecentes, como borboletas de asas úmidas recém-saídas de suas crisálidas opacas. Triunfantemente, os especialistas do pop proclamavam a morte e enterro dos velhos Beatles e o renascimento e ascensão dos novos Beatles. Pepper se tornou música sagrada, um hippie resurrectus. E que pena que não seu lançamento não foi na Páscoa!

Todas essas interpretações fantasiosas caem por terra a um leve toque da história. 0 designer da capa do disco, Peter Blake [autor do desenho no Ex.1], lembra que quando John e Paul o procuraram (com a recomendação de Robert Fraser, um cobiçado dono de galeria que criava as roupas dos novos astros do rock), eles tinham apenas a ideia de um concerto da banda em um parque. 'Poderíamos 
ter um coreto e um público', observou Blake, inspirado imediatamente com a visão de uma 'plateia mágica' (conceito que Paul McCartney também diz que foi seu): um mar de faces familiares e desconhecidas, juntas em uma fotomontagem. Blake sugeriu que os Beatles listassem os rostos que gostariam de ver na plateia, enquanto ele e Fraser também fariam suas próprias listas.

Ironicamente, foi Blake, que era pintor, quem escolheu o único cantor da música pop: Dion (de Dion and the Belmont), além de Leo Gorcey e Huntz Hall dos Dead end kids, alguns comediantes britânicos e seu amigo, o artista pop norte-americano Richard Merkin. Robert Fraser, que havia introduzido a pop art na Inglaterra, escolheu os pintores que ele admirava, liderados pelo proto-pop iconógrafo Richard Lindner. George Harrison incluiu uma tribo inteira de desconhecidos gurus indianos, entre eles Maharishi Mahesh Yogi. Alguns rostos, como Lenny Bruce e Terry Southern eram favoritos de todos os Beatles; outros eram ícones comercializados em qualquer loja de pôsteres. A lista mais excêntrica foi composta por Lennon, que saboreou este jogo: escolheu Jesus e Hitler; Aleister, o mais famoso ocultista da Inglaterra; Stephen Crane, um escritor de quem nunca mais falaria; Albert Stebbins, um velho jogador de futebol de Liverpool que Freddie Lennon [pai de John Lennon], era fã. Ringo foi o único do grupo que não quis indicar ninguém. Recusou o convite dizendo: 'O que os meninos escolherem tá bom prá mim!

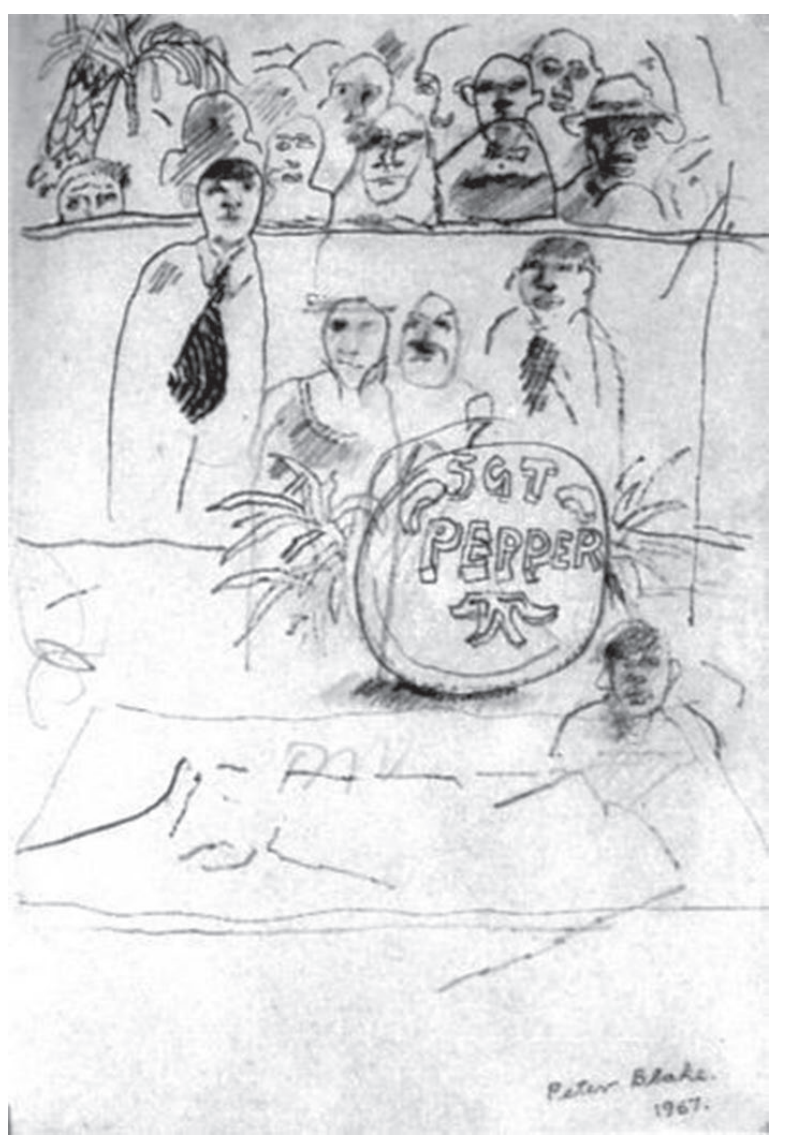

Ex.1 - Rascunho original de Peter Blake com a ideia da capa do disco Sgt. Pepper's Lonely Hearts Club Band dos Beatles (BEATLES, 1967/1987, p.8).
0 processo de composição da capa foi casual. Alguns poucos rascunhos, mas a maioria do trabalho consistiu de coletar e processar as imagens, o que foi feito pela esposa de Blake, Jann Howarth, que também era uma artista gráfica pop. Primeiro, as fotos [em preto e branco] foram agrupadas, depois ampliadas em tamanho real, coladas em papelão e recortadas como silhuetas. Colorido à mão e montado como cenário de teatro, o produto final ficou como um mural que ficava em pé sozinho, mas em uma escala muito maior do que caberia na foto. 0 objeto mais perto da câmara ficava a uma distância de 6 metros.

Assim que os artistas ergueram o mural, começaram a dispor objetos tridimensionais no primeiro plano. Cada um dos Beatles trouxe seus brinquedos. Paul contribuiu com uma coleção de instrumentos musicais. Blake tinha uma efígie de cera de Sonny Liston, o que o fez pensar que seria engraçado ter os Beatles [de cera] de Madame Tussaud olhando para a Banda do Sergeant Pepper, cujo bumbo havia sido decorado por um pintor de feira. $A$ ideia do canteiro de flores emblemático (o qual os norteamericanos confundiram com um túmulo) foi tirada de um pub britânico. Blake encomendou os buquês para a noite marcada para a sessão de fotos, planejando arranjálas como um símbolo qualquer, como de costume. Quando os Beatles cancelaram a sessão, as flores não sobreviveram em quantidade suficiente para realizar o design original. Então, uma assistente de 15 anos da floricultura se ofereceu para arranjar as flores restantes na forma de um violão. Assim, o mais famoso design foi criado numa combinação de improvisação e acaso.

Com todo esse trabalho em progresso, Brian Epstein estava uma pilha de nervos. Temia que estranhos estivessem ocupando o palco demais e, por isso, estava perdendo o controle do projeto. Por outro lado, quando chegou a hora de pagar a conta para o pacote tão cheio de nove-horas do disco, Brian não pode encarar...

Deixou a bola com Robert Fraser, cuja família de banqueiros se dava bem com Sir Joseph Lockwood, o Diretor da EMI, cujos negócios se baseavam na moagem de trigo. Fraser se deparou com Sir Joe na impressionante sala de reuniões da EMI: 'Você é menino de Lionel Fraser, não é?' retumbou o Diretor. 'Porque é que está metido nessa porcaria?' Fraser resmungou e gaguejou como um aluno de pré-primário. 'Quanto vai custar isso?' trovejou Sir Joe. '1.500 libras, senhor', resmungou Fraser. '1.500 libras!', explodiu o Diretor, irado. 'Posso contratar a London Symphony por isso!' (De fato, ele seria solicitado para fazer isso num futuro bem próximo).

Lockwood tinha todas as razões para ficar zangado. Uma capa de álbum da EMI geralmente era uma foto publicitária retocada pelo departamento de arte ao custo de aproximadamente 25 libras. Somente quando os Beatles concordaram em reembolsar a companhia pelas 1.500 libras se o álbum falhasse em vender 100.000 cópias, é que ele autorizou aquela demanda ultrajante. Mas ele não poupou Fraser, inquirindo astutamente: 'E 
quem é este fotógrafo, Michael Cooper? Você está nessa também?' Cooper era, na verdade, parceiro de Fraser.

Às 20:00 hs do dia 30 de março de 1967 os Beatles chegaram ao estúdio de Michael Cooper, na Flood Street №1, em Chelsea, onde trocaram de roupa, colocando os uniformes deslumbrantes das bandas de rua do século XIX, especialmente confeccionados no mais brilhantes cetins de ópera cômica pela agência Burman's Theatrical, adornado com as mais elaboradas insígnias e galões, chapéus e botas de verniz amarelas e laranjas feitas sob medida.

A sessão de fotos durou três horas [Ex.2], com os Beatles posando de diversas maneiras, enquanto os amigos de Robert Fraser enchiam o ar com o aroma atraente de haxixe marroquino. Os Beatles ficaram entusiasmados com toda aquela aventura. Tão entusiasmados que continuaram querendo adicionar novos elementos à embalagem da capa do disco. Agora, ao invés de um simples LP, decidiram oferecer ao público um álbum duplo, embrulhado como um presente de Natal com brinquedos de hippies: crachás de uniformes, uma camiseta e pôsteres de silhuetas. Naquele ponto, soou o alarme na EMI.

Lord Shawcross, um dos diretores da companhia, descobriu o que haveria no novo pacote do disco e imediatamente levantou objeções. Um álbum duplo estava fora de questão. Incluir na capa do disco todo o tipo de adereços tornaria impossível o empilhamento da mercadoria. Mas o pior, no seu ponto de vista, era a noção de cobrir o álbum com retratos de gente famosa ou obscura. Cada um dessas pessoas teria o direito de processar por uso indevido de imagem. A companhia perderia uma fortuna em litígio. Todo o projeto estava em risco. Esses argumentos causaram tanto impacto em Brian (que havia sido contra a ideia desde o início) que pensou em persuadir os Beatles a abandonar seu estimado plano. Quando eles foram taxativos, Brian entrou em pânico. Ligou para Wendy Hanson e a chamou imediatamente para resolver a questão da liberação das fotos.

No próximo mês, Wendy não fez nada além de contatar agentes e gerentes, buscando as assinaturas necessárias [dos fotografados; os Exs. Exs. 3, 4 e 5 mostram a artefinal da capa e a identificação de pessoas e objetos que permaneceram na foto final]. Algumas das estrelas, como Shirley Temple Black, um grande nome nos EUA, fizeram um monte de perguntas. Outros não não foram encontrados, como Karlheinz Stockhausen, que estava em um barco no Pacífico. Leo Gorcey [ator, membro dos Bowery Boys] se comportou como um Dead End Kid, querendo dinheiro para figurar na capa. Ele foi cortado, com também foi cortado Gandhi, cujo rosto foi considerado religioso demais para companhias tão profanas. ${ }^{8}$ Hitler ficou, ${ }^{9}$ mas Jesus teve de sair por causa da notória afirmação de John Lennon [de que os Beatles eram mais populares que Jesus; GOLDMAN, 1988, p.205]. Mae West respondeu o formulário com uma pergunta desafiadora: ' 0 que eu estaria fazendo em um Clube de Corações Solitários?' [Ao que os Beatles lhe escreveram uma carta pessoal e ela respondeu aceitando (BEATLES, 1967/1987, p.7)].

A batalha final ficou conta dos créditos. Primeiro, Paul disse: 'Sem créditos!' Então Robert Fraser persuadiu Paul a reconhecer o trabalho de Peter Blake e Michael Cooper. ${ }^{10}$ No final, ninguém foi mencionado, exceto George Martin, embora dezenas de músicos, técnicos e assistentes contribuíram com o projeto. 'Paul é muito mesquinho quando se trata de créditos', explicou Fraser, 'porque ele quer passar a ideia de que ele faz tudo sozinho.' Não estaria longe o dia em que esta percepção seria correta."

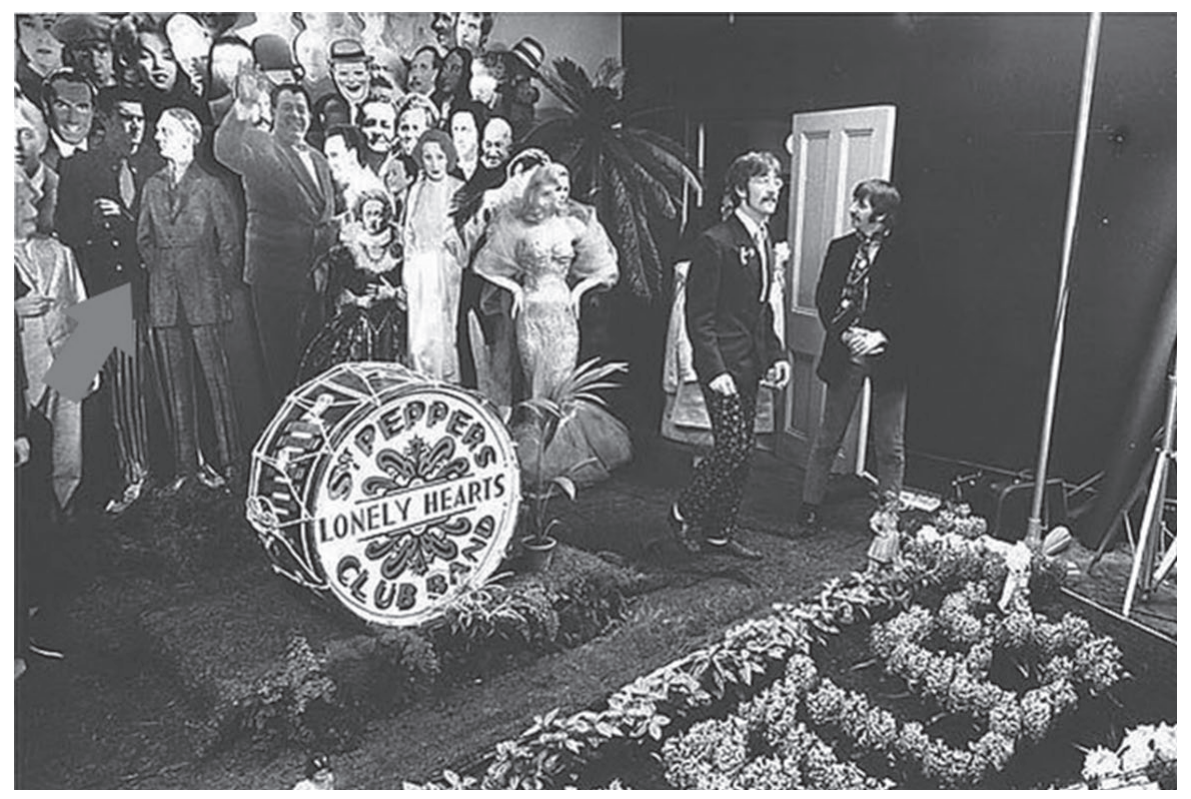

Ex.2 - John Lennon e Ringo Star no cenário quase pronto para a sessão de fotos da capa do disco Sgt. Pepper's Lonely Hearts Club Band dos Beatles em foto de Michael Cooper. Observe a foto de Hitler em posição à esquerda, mas que não aparece na foto final por ter ficado atrás dos Beatles (BEATLES, 1967/1987, p.9). 


\section{0 - Considerações finais}

"Sgt. Pepper foi como um grito ouvido ao redor do globo. Da noite para o dia recarregou a aura dos Beatles como a eletricidade da beatlemania: somente agora o brilho em torno da banda se tornou uma glória psicodélica. Um monumento à década de 1960, o álbum brilha com a excitação de uma era efervescente, de um mundo com dedos nervosos para acontecer. Embora os hippies sabichões fizessem de tudo para carregar o álbum com significados profundos $e$ portentosos, o sucesso do álbum se deveu mais ao inexplicável encanto que fez cada canção não sair da cabeça das pessoas. Insistentemente, o Sgt. Pepper era tocado nos lares. Nas rádios, os DJs viravam o LP de lado repetidamente, como se tivessem apenas esse disco, que é um tributo à habilidade de Paul em fazer funcionar uma engrenagem de canções pouco afins, e se tornar um tecido sem emendas.
0 triunfo de Paul foi, entretanto, uma vitória de Piro, uma vez que Sgt. Pepper marca o início da guerra fatal entre os líderes dos Beatles que, ao final, privaria o público do maior time de composição e gravação de música popular dos tempos modernos. A ira de John agora estava encoberta, mas acesa. Ficaria em banho-maria por mais um ano e, então, explodiria, varrendo tudo que tinha sido conquistado em uma década de trabalho árduo, autodisciplina severa, cooperação, inspiração sem fronteiras e, acima de tudo, uma total dedicação ao ideal de atingir o 'toppermost of the poppermost' ['o mais alto do mais pop']. Sgt. Pepper permanece no ponto mais alto."

Espero que os leitores de Per Musi interessados na história - musical e extramusical - de um dos maiores fenômenos da música popular tenham acesso não apenas a esse trecho, mas a todo o livro The Lives of John Lennon do controverso e minucioso Albert Goldman.

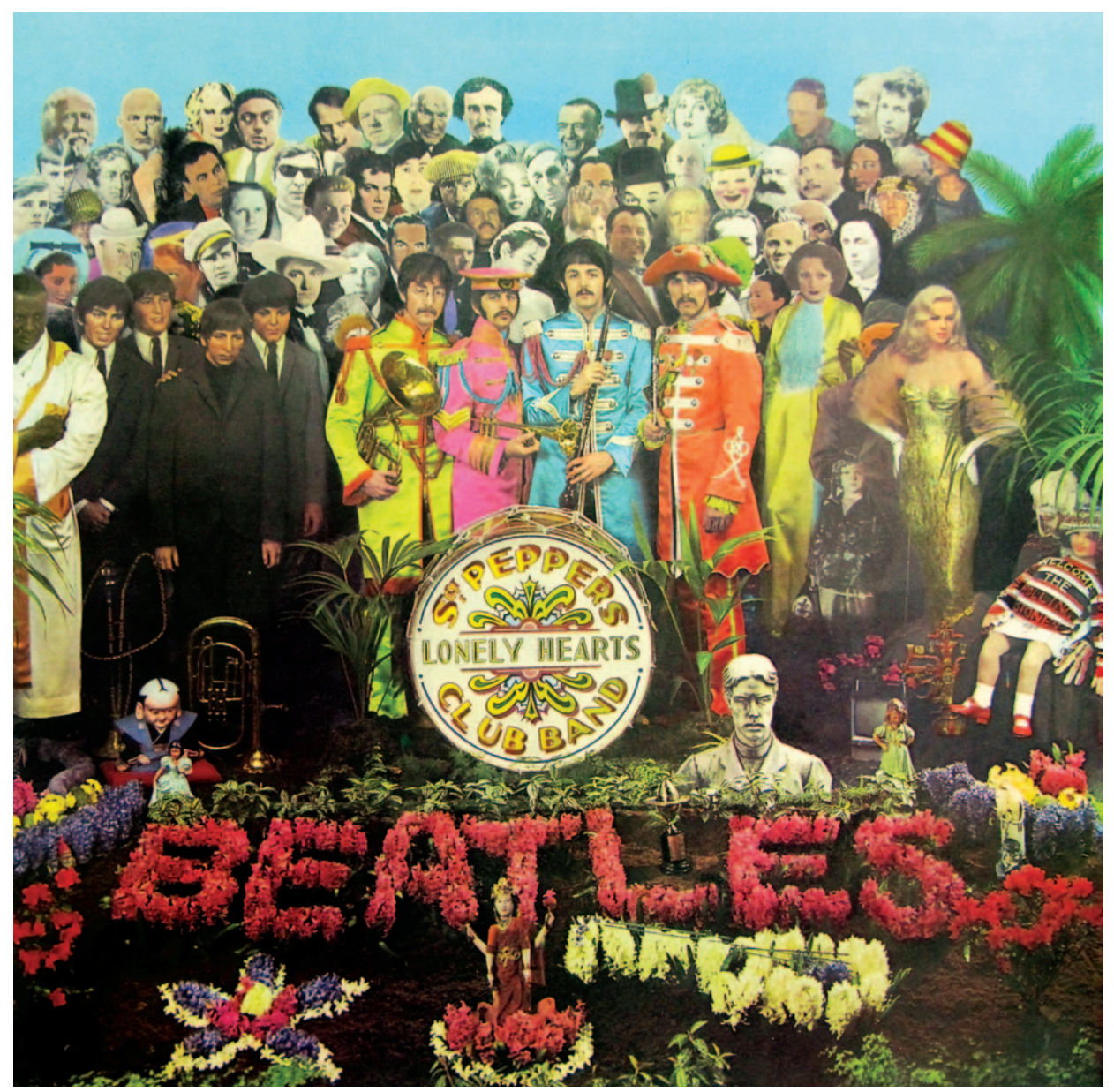

Ex.3 - Foto final de Michael Cooper para a capa do LP Sgt. Pepper, que inclui os Beatles com instrumentos musicais, as estátuas de cera do Beatles de Madame Tussaud, fotos recortadas de personalidades e diversos objetos pessoais dos envolvidos nas sessões de fotos (BEATLES, 1967/1987, p.1). 


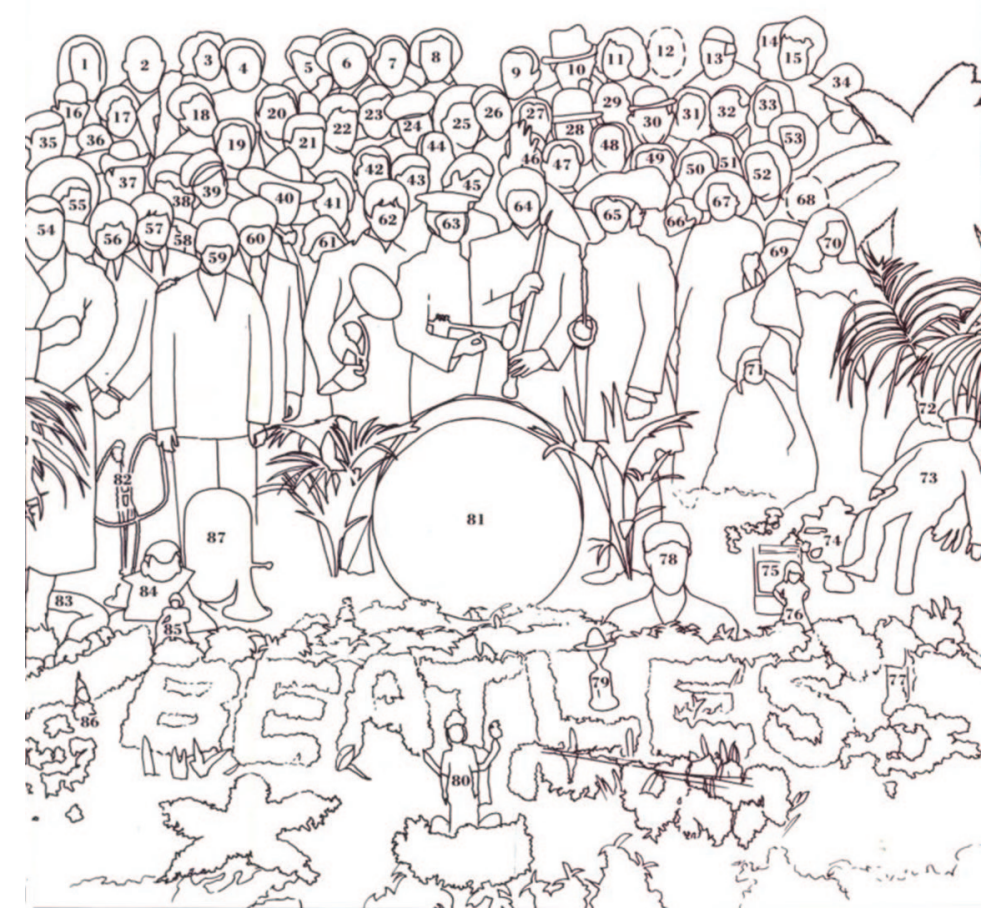

Ex.4 - Croqui de personalidades e objetos da capa do LP Sgt. Pepper (BEATLES, 1967/1987, p.2).

1. Sri Yukteswar Gigi (guru)

2. Aleister Crowley (diletante em sexo, drogas e mágica)

3. Mae West (atriz)

4. Lenny Bruce (cômico)

5. Karlheinz Stockhausen (composer)

6. William Claude Fields (cômico)

7. Carl Gustav Jung (psicólogo)

8. Edgar Allen Poe (escritor)

9. Fred Astaire (ator)

10. Richard Merkin (artista)

11. "The Varga Girl" (do artista Alberto Vargas)

12. *Leo Gorcey (ator, eliminado porque exigiu cachê)

13. Huntz Hall (ator principal dos Bowery Boys)

14. Simon Rodia (construtor das Watts Towers)

15. Bob Dylan (músico)

16. Aubrey Beardsley (ilustrador)

17. Sir Robert Peel (político)

18. Aldous Huxley (escritor)

19. Dylan Thomas (poeta)

20. Terry Southern (escritor)

21. Dion (di Mucci) (cantor)

22. Tony Curtiss (ator)

23. Wallace Berman (artista)

24. Tommy Handley (cômico)

25. Marilyn Monroe (atriz)

26. William Burroughs (escritor)

27. Sri Mahavatara Babaji (guru)

28. Stan Laurel (cômico)
29. Richard Lindner (artista)

30. Oliver Hardy (cômico)

31. Karl Marx (filósofo/socialista)

32. H. G. Wells (escritor)

33. Sri Paramahansa Yogananda (guru)

34. Anônimo (manequim de cera de cabelereiro)

35. Stuart Sutcliffe (artista e ex-Beatle)

36. Anônimo (manequim de cera de cabelereiro)

37. Max Miller (cômico)

38. "The Pretty Girl" (do artista George Petty)

39. Marlon Brando (ator)

40. Tom Mix (ator)

41. Oscar Wilde (escritor)

42. Tyrone Power (ator)

43. Larry Bell (artista)

44. Dr. David Livingston (missionário/explorador)

45. Johnny Weissmuller (ator de Tarzan/nadador)

46. Stephen Crane (escritor)

47. Issy Bonn (cômico)

48. George Bernard Shaw (escritor)

49. H.C. Westermann (escultor)

50. Albert Stubbins (jogador de futebol)

51. Sri lahiri Mahasaya (guru)

52. Lewis Carrol (escritor)

53. T. E. Lawrence (Lawrence da Arábia, soldado)

54. Sonny Liston (boxeador)

55. The Pretty Girl (do artista George Petty)

56. Estátua de cera de George Harrison

Ex.5 - Lista de identificação das personalidades e objetos da capa do LP Sgt. Pepper (BEATLES, 1967/1987, p.3). 


\begin{tabular}{|l|l|}
\hline 57. & Estátua de cera de John Lennon \\
\hline 58. & Shirley Temple (atriz-mirim) \\
\hline 59. & Estátua de cera de Ringo Starr \\
\hline 60. & Estátua de cera de Paul McCartney \\
\hline 61. & Albert Einstein (físico) \\
\hline 62. John Lennnon, segurando uma trompa \\
\hline 63. Ringo Starr, segurando um trmpete \\
\hline 64. Paul McCartney, segurando um corne inglês \\
\hline 65. George Harrison, segurando uma flauta \\
\hline 66. Bobby Breen (cantor) \\
\hline 67. Marlene Dietrich (atriz) \\
\hline 68. Mohandas Ghandi (eliminado a pedido da EMI) \\
\hline 69. Legionário das Ordem do Buffalos \\
\hline 70. Diana Dors (atriz) \\
\hline 71. Shirley Temple (atriz-mirim) \\
\hline 72. Boneca de pano de avó (de Jann Haworth) \\
\hline
\end{tabular}

\begin{tabular}{|ll|}
\hline 73. & Boneca de pano de Shirley Temple (de Jann Haworth) \\
\hline 74. & Vela mexicana \\
\hline 75. & Aparelho de TV \\
\hline 76. & Estátua de pedra de garota \\
\hline 77. & Figura de pedra \\
\hline 78. & Busto da casa de John Lennon \\
\hline 79. & Troféu \\
\hline 80. & Boneca indiana de 4 braços \\
\hline 81. & Bumbo com pele pintada por Joe Ephgrave \\
\hline 82. & Hookah (narguilé) \\
\hline 83. & Cobra de veludo \\
\hline 84. & Estátua de pedra japonesa \\
\hline 85. & Estátua de pedra de Branca de Neve \\
\hline 86. & Gnomo de jardim \\
\hline 87. & Tuba \\
\hline
\end{tabular}

74. Vela mexicana

76. Estátua de pedra de garota

77. Figura de pedra

78. Busto da casa de John Lennon

80. Boneca indiana de 4 braços

- Bumbo com pele pintada por Joe Ephgrave

83. Cobra de veludo

84. Estátua de pedra japonesa

85. Estátua de pedra de Branca de Neve

87. Tuba

Ex.5 (cont.) - Lista de identificação das personalidades e objetos da capa do LP Sgt. Pepper (BEATLES, 1967/1987, p.3).

\section{Referência de áudio e vídeo}

BEATLES. Sgt. Pepper's Lonely Hearts Club Band. Com Paul McCartney, John Lennon, George Harrison e Ringo Star; gravado e produzido por George Martin; engenheiro de som Geoff Emerick; capa de M. C. Productions e The Apple; cenários de Peter Blake e Jann Haworth; fotos de Michael Cooper; figuras de cera de Madame Tussauds; design de embalagem de Katheyn Verley; notas no encarte de George Martin, Mark Lewisohn e Peter Blake. EMI, 1967 (CD remasterizado EMI CDP 746442 2, 1982).

ELLER, Cássia. Sgt. Pepper's Lonely Hearts Club Band. In: Cássia Eller: Acústico MTV. Com Cássia Eller, Luiz Brasil, Alberto Continentino, Paulo Calasans, João Viana, Bernard Bessler, Dirceu Leite, Cristiano Alves, Yura Ranevsky, Walter Villaça, Fernando Nunes, Lan Lan e Thamyma. Participação de Nando Reis, Xis e Nação Zumbi. Direção de Nando Reis e Luiz Brasil. Universal Music, 2001. (DVD).

\section{Referências de livros}

COLEMAN, Ray. John Winston Lennon. London: Sidgwick \& Jackson, 1984 John Ono Lennon. London: Sidgwick \& Jackson, 1984

DAVIES, Hunter. The Beatles. New York: McGraw Hilll, 1968.

GAINES, Steven. The love you make. New York: McGraw Hilll, 1983.

GOLDMAN, Albert. The Lives of John Lennon. New York: William Morrow and Co., 1988.

GREEN, John. Dakota days. New York: St. Martin's Press, 1983.

LEWISOHN, Mark. The Beatles live! London: Michael Joseph, 1986.

MARTIN, George; HORNSBY, Jeremy. All you need is ears. New York: St. Martin's Press, 1980.

MELLER, Wilfrid. Twilight of the gods. New York: Schirmer, 1973.

PANG, May; EDWARDS, Henry. Loving John. New York: Warner Books, 1983.

SHOTTON, Pete; SCHAFFER, Nicholas. John Lennon in my life. New York: Stein \& Day, 1983.

\section{Referências de entrevistas}

GOLDMAN, Albert. Entrevista de John Lennon a Albert Goldman em dezembro de 1970. In: Charlie, junho-julho, 1971. MCCABE, Peter; SCHONFELD, Robert D. John Lennon: for the record. Entrevista de John Lennon a Peter Mccabe e Robert

D. Schonfeld em agosto de 1971. New York: Bantam, 1984.

SHEFF, David. The Playboy interviews with John Lennon \& Yoko Ono. Ed. Barry Golson. Entrevista de John Lennon a David Sheff no outono de 1982. New York: Playboy, 1982.

WENNER, Jann. Entrevista de John Lennon a Jann Wenner em dezembro de 1970. In: Rolling Stones. (Publicada posteriormente como Lennon remembers. New York: Fawcett, 1972). 


\section{Referências da internet}

BRINK, Lauren. The Music History Workspace. Org. por Laura Dolp. Montclair, New Jersey: John J. Cali School of Music at Montclair State University. In: http://msumusichistory.pbworks.com/w/page/39413079/Lauren\%20-020Sgt\%20 Pepper's (Acesso em 30 de agosto, 2012).

GRAVES, Tom. Rock's backpages: the ultimate library of rock music writing. In: http://music.yahoo.com/blogs/rocksbackpages/rock-biographys-bete-noire-in-defense-of-albert-goldman.htmln (acesso em 25 de julho, 2012).

GRIMES, William. Albert Goldman, biographer, is dead at 66. New York Times; Obituaries. 30 de março, 1994. In: http:// www.nytimes.com/1994/03/30/obituaries/albert-goldman-biographer-is-dead-at-66.html (Acesso em 30 de julho, 2012).

LOS ANGELES TIMES. Albert Goldman; Biographer of Presley, Lennon. Los Angeles Times; Obtiuaries. In: http://articles. latimes.com/1994-04-01/news/mn-40898_1_albert-goldman (Acesso em 30 de julho, 2012).

EMERICK, Geoff; MARTIN, George; BEATLES. Deconstructing Sgt. Pepper. Org. por Sunnuvapuz para Youtube. In: http:// www.youtube.com/watch?feature=player_detailpage\&v=c-wXZ5-Yxuc (Acesso em 1 de agosto, 2012).

\section{Notas}

1 GOLDMAN (1988, p.195, 198, 248, 568) menciona várias referências do Tibetan book of the dead [0 Livro tibetano dos mortos] na vida de John Lennon.

20 Mellotron é um sintetizador eletromecânico de possibilidades sinfônicas, surgido na Inglaterra no início da década de 1960 e que foi utilizado pelos Beatles em 1966 na canção Strawberry Fields Forever.

3 Mark Lewisohn (BEATLES, 1967/1987, p.4) chama a atenção para o fato de que, se Sgt. Pepper gastou 700 horas de gravação, Please please me, o primeiro álbum dos Beatles, gastou menos de 10 horas (precisos 585 minutos).

4 A marca HMV, ou His Master's Voice [A Voz do seu dono], cujo nome deriva da famosa pintura em que um cachorrinho escuta um gramofone, é uma marca registrada da gravadora Gramophone.

5 A gravação de cada um quatro canais disponíveis em Sgt. Pepper pode ser apreciado separadamente e, depois, em conjunto no Youtube em http://www. youtube.com/watch?feature=player_detailpage\&v=c-wXZ5-Yxuc: Canal 1(verde): duas guitarras, baixo e bateria ; Canal 2 (azul): metais e guitarra com distorção; Canal 3 (vermelho): vocais ; Canal 4 (amarelo): sons da plateia, orquestra mixado com os demais canais (EMERICK, MARTIN, BEATLES, 2012).

6 Além de George Martin, o termo "quinto Beatle" também foi usado com frequência para designar mais três pessoas: o músico Pete Best, que se juntou aos Beatles para os concertos em Hamburgo no início da carreira, com o nome The Silver Beetles ou The Silver Beatles (GOLDMAN, 1988, p.98); Stuart Sutcliffe, amigo de juventude de John Lennon (GOLDMAN, 1988, p.83-84, 117-118); e o empresário dos Beatles Brian Epstein (GOLDMAN, 1988, p.112-113). Mas para George Harrison, quem deveria de fato receber este "título" seria o relações públicas da Apple Derek Taylor (GOLDMAN, 1988, p.171-172, 299) ou o executivo dos Beatles Neil Aspinall (GOLDMAN, 1988, p.171).

7 Toby mugs são canecas de cerâmica típicas da Inglaterra, geralmente com caricaturas alegres de marinheiros.

8 A figura de Gandhi foi substituída por uma palmeira na capa de Sgt Pepper, pois a gravadora EMI julgou que isso poderia ser visto como ato ofensivo na Índia e na China, paises em que gravadora tinha negócios.

9 Embora a foto recortada de Hitler tenha permanecido para a sessão de fotos (veja Ex.2 acima), acabou escondida atrás dos Beatles na foto final da capa (BEATLES, 1967/1987, p.9). Fazendo coro ao espírito debochado de John Lennon, Cássia ELLER (2001), na sua gravação da faixa Sgt. Pepper's Lonely Hearts Club Band no vídeo Acústico MTV, diz ao final "Love Hitler!" (a cerca de 51 minutos e 19 segundos do início).

10 Peter Blake afirma que não tem ideia de quanto toda a operação da capa do Sgt. Pepper custou, mas acha que todos exageraram. Ele diz que Robert Fraser recebeu 1.500 libras da EMI e ele apenas 200 libras. E após o sucesso do disco, não recebeu nem um centavo, porque Fraser assinou a liberação de direitos autorais (BEATLES, 1967/1987, p.7)

Albert Harry Goldman (1927-1994), escritor norte-americano, obteve seu Mestrado pela University of Chicago em 1950 e o Ph. D. em Inglês pela Columbia University em $1961 \mathrm{com}$ a tese The Mine and the Mint: Sources for the Writings of Thomas De Quincey (Southern Illinois University Press, 1965). Foi professor na City University of New York e na Columbia University (1963-1972). É autor de biografias polêmicas como as que publicou sobre Lenny Bruce (Ladies and Gentlemen - Lenny Bruce!, 1974), Elvis Presley (Elvis, 1981; Elvis: The Last 24 Hours, 1990) e John Lennon (The Lives of John Lennon, 1988). Outros livros de sua autoria incluem Freakshow: misadventures in the counterculture: 1959 - 1971 (2001), Sound bites (1992), Disco (1979), Carnival in Rio (1978), Grass Roots: marijuana in America today (1979) e The Mine and the mint: sources for the writings of Thomas de Quincey (1965), entre outros. Com Everet Sprinchorn, publicou Wagner on Music and Drama.

Fausto Borém é Professor Titular da Escola de Música da Universidade Federal de Minas Gerais (UFMG), onde criou o Mestrado e a Revista Per Musi e organizou diversos eventos nacionais e internacionais. É pesquisador do CNPq desde 1994 e seus resultados de pesquisa incluem dois livros, três capítulos de livro, dezenas de artigos sobre práticas de performance e suas interfaces (composição, análise, musicologia, etnomusicologia e educação musical) em periódicos nacionais e internacionais, dezenas de edições de partituras e recitais nos principais eventos nacionais e internacionais de contrabaixo. Recebeu diversos prêmios no Brasil e no exterior como solista, teórico, compositor e professor. Acompanhou músicos eruditos como Yo-Yo Ma, Midori, Menahen Pressler, Yoel Levi, Fábio Mechetti, Arnaldo Cohen e músicos populares como Hermeto Pascoal, Egberto Gismonti, Henry Mancini, Bill Mays, Kristin Korb, Grupo UAKTI, Toninho Horta, Juarez Moreira, Tavinho Moura, Roberto Corrêa e Túlio Mourão. Editou os números 22, 23, 28, 29 e 30 da Revista Per Musi, conjunto com mais de 1.000 páginas de trabalhos acadêmicos dedicados à pesquisa sobre música popular. 